\title{
XIV. Yüzyılın İlk Yarısında Anadolu İslam'ına Dair Gözlemler: İbn Battûta Örneği
}

\author{
Murat KEÇIŞ̧
}

Doç. Dr., Muğla Sitkı Koçman Üniversitesi, Edebiyat Fakültesi, Tarih Bölümü, Muğla, Türkiye, muratkecis@ mu.edu.tr (Sorumlu Yazar/Corresponding Author)

\section{Canan ÖZTÜRK}

Yüksek Lisans Öğrencisi, Hacettepe Üniversitesi, Edebiyat Fakültesi, Tarih Bölümü, Ankara, Türkiye, cnozturk016@ gmail.com

\begin{tabular}{|c|c|}
\hline Makale Bilgileri & ÖZ \\
\hline $\begin{array}{l}\text { Geliş: } 15.11 .2021 \\
\text { Kabul: } 16.12 .2021 \\
\text { Yayın: } 31.12 .2021 \\
\text { Anahtar Kelimeler: } \\
\text { İbn Battûta, } \\
\text { Anadolu, } \\
\text { XIV. Yüzyıl, } \\
\text { Türkiye Selçukluları, } \\
\text { Fas. }\end{array}$ & 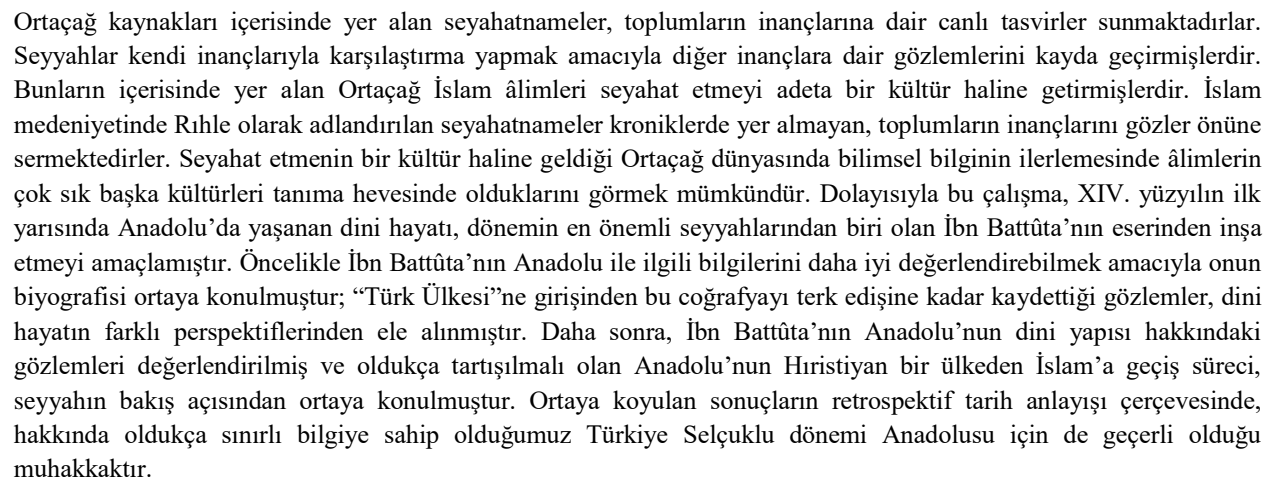 \\
\hline
\end{tabular}

\section{Observations on Islam of Anatolian in the First Half of the 14th Century: The Case of Ibn Battuta}

\begin{tabular}{|c|c|}
\hline Article Info & ABSTRACT \\
\hline Article History & $\begin{array}{l}\text { avels in medieval sources offer vivid descriptions of the beliefs of societies. Travelers recorded their observations of } \\
\text { eer beliefs in order to compare them with their own. Medieval Islamic scholars, who are among them, made travel a }\end{array}$ \\
\hline & lture. Travels called Rihle in Islamic civilization reveal the beliefs of societies that are not included in the chronicles. \\
\hline & ery often eager to get to \\
\hline Published: 31.12 .2021 & $\begin{array}{l}\text { know other cultures for the advancement of scientific knowledge. Therefore, this article aims to introduce the religious } \\
\text { life lived in Anatolia in the first half of the 14th century from the work of Ibn Battuta, one of the most important }\end{array}$ \\
\hline Keywords: & avelers of the period. First of all, Ibn Battûta's biography reveal in order to better evaluate his knowledge of Anatolia; \\
\hline $\begin{array}{l}\text { İbn Battuta, } \\
\text { Anatolia, } \\
\text { 14th Century, } \\
\text { The Saljuqgs of Turkey, }\end{array}$ & $\begin{array}{l}\text { the observations he recorded from his entrance to the "Türkiye" to his departure from this geography discusses from } \\
\text { different perspectives of religious life. Then, Ibn Battûta's observations on the religious structure of Anatolia evaluate, } \\
\text { and the highly controversial process of Anatolia's transition from a Christian society to an Islamic society reveal from } \\
\text { the traveler's point of view. It is certain that the results we evplain also be valid for Anatolia during the Seljuq period, } \\
\text { about which we have very limited information, within the framework of the retrospective understanding of history. }\end{array}$ \\
\hline
\end{tabular}

Atıf/Citation: Keçiş, Murat - Öztürk, Canan. "XIV. Yüzyılın İlk Yarısında Anadolu İslam'ına Dair Gözlemler: İbn Battûta Örneği”. Selçuklu Medeniyeti Araştırmalarl Dergisi (SEMA) 6 (Aralık 2021), 71-82. https://doi.org/10.47702/sema.2021.16 
"Rum Diyarı diye bilinen bu ülke, dünyanın belki en güzel memleketi! Allah Teâlâ güzellikleri öbür ülkelere ayrı ayrı dağıtırken burada hepsini bir araya toplamış! Dünyanın en güzel insanlar, en temiz klyafetli halk burada yaşar ve en leziz yemekler de burada pişer. Allah Teâlâ'nın yarattığı kullar içinde en şefkatli olanlar buranın halkıdır. Bu yüzden şöyle denilir:

"Bolluk ve bereket Sam diyarında, sevgi ve merhamet ise Rum'da!" Bu kelimeyle buranin halkı kastolunuyor.,",

İbn Battûta, 1332, Anadolu

\section{GİRIȘ}

İbn Battûta'nın verdiği bilgileri Anadolu din tarihi açısından değerlendirirken, bu dönemi iki zıt paradigma şeklinde ele alan çalışmaları dikkate almalıyız. Birinci paradigma Hıristiyan nüfusun İslamlaşması fikrini temel alan Oryantalist bakış açısıdır. ${ }^{2}$ İkincisi ise göç hareketidir. İlk paradigma daha çok din değiştirme üzerinde dururken göç hareketi büyük bir değişime vurgu yapmaktadır. Anadolu'nun Hıristiyan Romalıların ve Ermenilerin ülkesinden Türkiye diye tabir edilen vatana dönüşmesi uzun ve anlaşılması oldukça karmaşık bir süreçtir. Fuad Köprülü bu din değiştirme bakış açısına şiddetle karşı çıkarak Orta Asya'dan gelen büyük göç hareketine vurgu yapar. ${ }^{3}$ İbn Battûta'nın Anadolu gözlemleri de bu göç ve yeni bir medeniyet inşa etme sürecini doğrular niteliktedir. Ahmet Yaşar Ocak'ın da değindiği gibi Anadolu Türk Tarihi içerisinde en az çalışılan alanlardan biri Türkler ve İslam'dır. Bu açıdan özellikle Anadolu İslam'ının en karanlık dönemi olarak görülen geç Ortaçağı'nda Anadolu'da İslam'ın nasıl yaşandığına dair elimizde oldukça sınırlı bilgi bulunmaktadır. ${ }^{4}$ $\mathrm{Bu}$ noktadan hareket ederek XIV. yüzyılın en önemli seyyahı olarak kabul edilen İbn Battûta'nın oldukça geniş bir coğrafya hakkında verdiği bilgilerden, Anadolu hakkındakileri ele alarak bu çalışmayı belli bir alanda tutmak ve bu şekilde daha derinlemesine bir araştırma yapmaya çalışmak daha doğru bir yaklaşım olacaktır. ${ }^{5}$

İbn Battûta, Anadolu'ya günümüzde Alanya olarak isimlendirilen Alâyâ ya da Alaiye liman şehrinden giriş yaptıktan hemen sonra Anadolu'nun dini yapısı hakkında bilgi vermektedir. Bu durum Ortaçağ’ın değerli seyyahının gezdiği yerleri anlatırken dini bir amaç taşıdığını göstermektedir. ${ }^{6}$

${ }^{1}$ İbn Battûta'nın Arapça olarak kaleme aldığı eseri XIX. yüzyılın sonlarından itibaren dikkat çekmeye başlamıştır. Eser üzerine yapılan bütün çalışmalar Sait Aykut tarafindan çok detaylı bir şekilde izah edilmiştir. Bk. A. Sait Aykut, "İbn Battûta”, Türkiye Diyanet Vakfi Islâm Ansiklopedisi (İstanbul: TDV Yayınları, 1999), 19/365-368. Eser Sait Aykut tarafindan oldukça başarılı bir şekilde Türkçeye kazandırılmış olup biz de çalışmamız sırasında bu tercümeden istifade edeceğiz. Ebû Abdullah Muhammed İbn Battûta Tancî, İbn Battûta Seyahatnamesi, çev. A. Sait Aykut (İstanbul: Yapı Kredi Yayınları, 2019), 273.

${ }^{2} \mathrm{Bu}$ görüşün en ateşli savunucusu Speros Vryonis'tir. Bu alanda birçok araştırma yapmıştır fakat en belirgin olanı için Bk. Speros Vryonis, The Decline of Medieval Hellenism in Asia Minor and the Process of Islamization from the Eleventh through the Fifteenth Century, (Berkeley- Los Angeles- Londra: University of California Press, 1971, yeniden basım 1986).

${ }^{3}$ Mehmet Fuad Köprülü, Anadolu'da İslamiyet (İstanbul: Alfa Yayınları, Mart 2017), 15.

${ }^{4}$ Ahmet Yaşar Ocak, Türkiye Sosyal Tarihinde İslam'ın Macerasl, Makaleler İncelemeler (İstanbul: Timaş Yayınları, 2010), 7.

${ }^{5}$ İslam seyahat kültürünün en önemli temsilcisi İbn Battûta üzerine Türkiye'de iki tez yapılmıştır. Batıda ise birçok çalışma vardır. Bunların ikisi aşağıda tam bibliyografik künyelerini de vereceğimiz Ross E. Dunn ve David Waines tarafından yazılan müstakil kitaplardır. Suat Karaman, İbn Battûta'nın Anadolu kültür hayatı hakkında verdiği bilgileri değerlendiren bir yüksek lisans tezi hazırlamıştır. Bu tezde Anadolu dini hayatı hakkında bir bölüm olmasına rağmen, dönemin dini hayatı hakkında oldukça genel bilgiler verildikten sonra seyyahın kayıtları çok yüzeysel bir şekilde değerlendirilmiş̧ir. Suat Karaman, İbn Battûta'ya Göre XIV. Yüzyll Anadolu Kültür Hayatı (Karabük: Karabük Üniversitesi, Sosyal Bilimler Enstitüsü, Yüksek Lisans Tezi, 2015), 26. İbn Battûta hakkında yazılan diğer bir tez; Meryem Altıntaş, İbn Battûta'ya Göre Anadolu Şehirlerinde Siyâsî, Din̂̂, İlmî̀, İçtimâ̂̀ ve İktisâdî Hayat (İstanbul: İstanbul Üniversitesi, Sosyal Bilimler Enstitüsü, Yayınlanmamış Yüksek Lisans Tezi, 2019).

${ }^{6}$ İbn Battûta, İbn Battûta Seyahatnamesi, 273. 
Battuta'nın seyahatine çıkması ve gezdiği İslam diyarları hakkında derin bilgiler vermesinin temel gayesi, burada da görüldüğü üzere, İslam dünyasının çok kapsamlı bir fotoğrafını çekmektir. ${ }^{7}$ İbn Battûta, XIV. yüzyılda İslam'ın kültürel sınırlarının Orta Doğu'nun ya da Arapların yaşadığı toprakların çok ötesine geçmiş bir uygarlık olduğunu en canlı bir şekilde tasvir etmektedir. ${ }^{8}$ Bu açıdan İbn Battûta'nın Anadolu'nun kültürel haritasını çıkarırken öncelikli hedefi İslam'ın bu coğrafyada nasıl algılandığını ve yaşandığını göstermek istemesidir. Bunu yaparken de Anadolu'yu bütün İslam dünyası ile karşılaştırır. İbn Battûta, Tebriz'e yaptığı yolculuk hariç ilk defa Müslüman halkın çoğunun Türk olduğu bir memleketi ziyaret ediyordu. Döndüğünde kendisi tarafindan Tuhfetü'nnüz̧zâr fî̀ garâ' ibi'l-emsâr ve 'acâ'ibi'l-esfâr diye adlandırılan ve literatürde Riḥletü İbn Bațtuṭta adıyla bilinen eser, seyyahın kısa aralıklarla yirmi sekiz küsur yıl süren gezilerini kâtip İbn Cüzey elKelbî’ye yazdırmasıyla ortaya çıkmıştır.

\section{1. İbn Battûta'nın Seyahati}

Seyyahımızın Anadolu İslam'ı ile ilgili verdiği bilgileri değerlendirmeden önce hayatının belli başlı dönemleri hakkında kısaca bilgi vermek faydalı olacaktır. Ortaçağ İslam dünyasının en büyük seyyahlarından biri olarak kabul edilen İbn Battûta 25 Şubat 1304 tarihinde Fas'ın Tanca şehrinde doğmuş ve 1368 yılında Marekeş kadısıyken vefat etmiştir. 22 yaşında iken, dini ilimlerde biraz ilerlemiş fakat herhangi bir alanda derinleşememiş bir genç olarak Hacca gitmek üzere memleketinden ayrılmış ve karadan İskenderiye'ye kadar yaptığı yolculuğun kısmen iyi geçmesine rağmen, uğradığı yerlerde din ve hukuk işlerinden anlar bir adam sıfatıyla hürmet ve itibar görmesi, yüksek şahsiyetler ile tanışması gibi güzel şeyler, onun maceraperest araştırmacı ruhunu kamçılamış ve çeyrek asır sürecek seyahatlerinin başlamasına sebep olmuştur. ${ }^{9}$

İbn Battûta, Nil bölgesini ve Antakya'ya kadar bütün Suriye'yi ${ }^{10}$ gezdikten sonra çöl üzerinden Hicaz'a giderek yaptığ 1 ilk haccının (1328) sonrasında, Irak'1, Fars diyarın ${ }^{11}$ ve Mardin'e kadar bütün Mezopotamya'yı ziyaret etmiştir. 1329-1330 senelerini Mekke'de geçirdikten sonra, Yemen bölgesini dolaşarak Somali'ye çıkmıştır. Umman, Bahreyn ve Yemame üzerinden üçüncü defa Hicaz'a gitmiş ve hayatının geri kalanında durumu elverdikçe Mekke'ye uğramıştır. ${ }^{12}$ Böylece her firsatta Kâbe'yi ziyaret eden İbn Battûta, seyahatnamesinde İslam dünyasını şeyhler, evliyalar, zaviye ve medreseler âlemi şeklinde aksettirmiştir. ${ }^{13}$

\footnotetext{
${ }^{7}$ İbn Battûta'nın eserinde genel akışa uymayan bazı bölümler vardır. Örneğin Dımaşk Emevi Camii ve Kâbe'nin tasvirlerini yaparken VIII. yüzyılda eserini kaleme alan İbn Cübeyr gibi seyyahların eserlerinden istifade etmiştir. İbn Cübeyr, Endülüsten Kutsal Topraklara, çev. İsmail Güler (İstanbul: Selenge Yayınları, 2003).

${ }^{8}$ Ross E. Dunn, İbn Battuta'nın Dünyası, çev. Yeşim Sezdirmez (İstanbul: Klasik Yayınları, 2004), VII.

${ }^{9}$ İbn Battûta, İbn Battûta Seyahatnamesi, 11.

${ }^{10}$ İbn Battûta'nın Suriye ve Arabistan seyahati hakkında yapılan değerlendirme için Bk. Adel Allouche, "A Study of Ibn Battūtah's Account of His 726/1326 Journey Through Syria and Arabia", Journal of Semitic Studies, 35/2, (Autumn 1990).

11 İbn Battûta'nın eserine göre İran'da sosyal hayat hakkında Bk. Mehlika Üstündağ, "İbn Battuta Seyahatnamesine Göre XIV. Yüzyıl İran Coğrafyasında Sosyal Yaşam”, Iraniyat Dergisi / Journal of Iranian Studies, I/2 (2017), 45-65. XIV. yüzyılda İran'daki tasavvufî kurum ve şahsiyetler hakkında Bk. Abdulcebbar Kavak, "Seyyah İbn Battûta'nın Gözüyle 14. Asır İran Toplumunda Tasavvuf”, Şırnak Üniversitesi İlahiyat Fakültesi Dergisi 11/25 (Aralık 2020).

12 İbn Battûta Tanci, İbn Battûta Seyahatnamesi, (2 cilt), çeviri, inceleme ve notlar: A. Sait Aykut, (İstanbul: YKY, 2004), 20. Bu makalenin yazımında Said Aykut tarafından yapılan tercümenin iki farklı baskısı kullanılmıştır, aksi belirtilmedikçe 2019 baskısı kullanılacaktır. Bu yola başvurulmasının sebebi, eserin 2004 yılındaki baskısının İbn Battuta'nın hayatı ile ilgili önemli hususları ele almış olmasıdır.

13 İbn Battûta'nın sosyolojik açıdan çözümlemesi için bk. Betül Ok Şehitoğlu, Seyahatname Sosyolojisi İbn Batuta'nın Gizemli Dünyasına Sosyolojik Bir Bakış (Konya: Çizgi Kitabevi, 2021).
} 
İbn Battûta buradan tekrar Suriye’ye gitmiş ve Lazkiye limanından bindiği bir Ceneviz gemisi ile Alanya'da Selçuklu ülkesine ayak basmıştır. Antalya-Burdur-Isparta-Eğirdir-Gölhisar-AcıpayamDenizli-Tavas üzerinden Milas'a ulaşmıştır. Eserinde yazdığına göre Konya-Karaman-AksarayNiğde-Kayseri-Sivas-Gümüşhane-Erzincan-Erzurum'a kadar yaptı̆̆ 1 seyahatin devamında Birgi'den kuzeye doğru yoluna devamla Manisa-Bergama-Balıkesir-büyük bir kent olarak bahsettiği Bursaİznik-Geyve-Göynük-Mudurnu-Bolu-Gerede-Safranbolu-Kastamonu'yu ziyaret etmiştir. Buradan Sinop'a ulaşmış ve Sinop limanında bindiği gemi ile Kırım'a geçmiştir. ${ }^{14}$ Güney Rusya (Deşt-i Kıpçak) ülkesinde Altın-Orda hükümdarı Özbek Han'ın ordugâhına varmıştır. Bulgar ülkesine geçen İbn Battûta buradan İstanbul'a hareket etmiştir. Doğu Avrupa'nın güneyine varınca Özbek başkenti Saray şehrinde bir müddet kaldıktan sonra, sırası ile Harezm, Maveraünnehr, Horasan ve Afganistan'ın büyük merkezlerini görmüştür. ${ }^{15}$

Hindistan gezisi ile Seyahatname'nin ikinci kısmı başlar. ${ }^{16}$ İndus havalisini ve Multan'1 ziyareti sonrasında doğuda bulunan İslam şehirlerinin en büyüğü dediği Delhi’ye varan İbn Battûta, burada kadılık ve diğer vazifeleri sebebiyle 7 sene kaldı. 1342 yılı başlarında Muhammed Tuğluk Han'ın emri ile ve resmi elçisi sıfatı ile Çin'e gitmek üzere yola koyuldu. Seyahatinin başlarında karşılaştığ1 güçlükler sebebiyle geri dönmek zorunda kalmasına rağmen, Hindistan'ın batı sahillerini görme imkânı buldu. Hind Okyanusu'nda Maldiv Adalarındaki Müslümanlara bir buçuk sene kadılık yaptıktan sonra doğu Hindistan kıyılarına Bengale'ye, Cava (Sumatra)'ya gitti ve Tavalisi adas1 üzerinden Çin'e girip, güney Çin'e doğru ilerleyerek Hanbalık (Pekin) kentine ulaştı. ${ }^{17}$ Çin'de yaşanan siyasi gelişmelerden rahatsız olarak, vatanına dönmeye karar veren İbn Battûta gittiği yollardan geri dönmek üzere, 1347 yılı başında Yemen limanında ve Irak-Suriye, Mısır üzerinden geniş bir kavis çizdikten sonra 1348 yılında Mekke'ye ulaştı. Buradan İskenderiye'ye gitmiş, deniz yolu ile Fas'a vararak Sultan Ebu İnan tarafından kabul edilmiştir (1349). Fakat İbn Battûta'nın seyahat hevesi, daha doğrusu bütün İslam âlemini görme merakı bitmemişti. Cebel-i Tarık boğazından İspanya'ya geçti. Endülüs'ün başlıca Müslüman şehirlerini dolaştı. Geri dönüş yolculuğunda övgüyle bahsettiği Marekeş kentini gezdi. Nihayet Müslümanların bulunduğu son ülkeyi de gezmek amacıyla Sudan ve Nijerya'ya doğru hareket etti. 1353 yılı sonlarına doğru seyahatini bitirmiş ve amacına ulaşmış olarak Fas'a geri döndü. ${ }^{18}$ İbn Battûta bu sırada 49 yaşında idi. 1369 yılında öldüğüne göre bir süre daha seyahatlerine devam edebilirdi. Buna gerek duymamasının sebebi herhalde onun nazarında artık görülmeye değer yer kalmamış olmasıdır. İbn Battûta'nın tüm gezileri hesap edildiğinde karşımıza 73.000 mil (117.482 kilometre) gibi büyük bir rakam çıkar. Yirmi dokuz sene boyunca, her çeşit zorluklara katlanarak İslam dünyasını dolaşan İbn Battûta'nın hızının kesilmesinin belki de en önemli sebebi İslamiyet'in yaşandığı ülkelerin hemen hemen büyük kısmını gezmiş olmasıdır. Ona göre

${ }^{14}$ İbn Battûta'nın Karadeniz ile ilgili verdiği bilgiler için Bk. Tahsin Koçyiğit, “İbn Battûta’nın Karadeniz seyahati üzerine bazı mülahazalar”. Din Bilimleri Akademik Araşttrma Dergisi 9/4(2009).

${ }^{15}$ İbn Battûta, İbn Battûta Seyahatnamesi, 2004, 22.

${ }^{16}$ İslam tarih yazıcılı̆̆ının en önemli isimlerinden İbn Haldun, Mukaddime'sinde İbn Battûta'nın naklettiklerinin büyük kısmının Hint hükümdarlarına dair olduğunu ve bu hikâyeleri dinleyenlerin garipsediğini ifade etmiştir. İbn Haldun, Seyahatname'de anlatılanları -en azından Hint hükümdarlarına dair anlatıları- çok gerçekçi bulmamaktadır. İbn Haldun, Mukaddime, haz. Süleyman Uludağ, I, 4. Baskı, (İstanbul: Dergah Yayınları, 2005), 410. Bu bahse dair, eserin Zakir Kadri Ugan tarafindan yapılan tercümesinde, Uludağ tercümesinde bulunmayan şu cümle vardır: "İbn Batuta'nın yalancı olduğunu fisıldaşarak konuşurlardı." İbn Haldun, Mukaddime, çev. Zakir Kadirî Ugan, C. I, (İstanbul: Milli Eğitim Bakanlığı Yayınları, 1990), 458. Vermiş olduğu bilgileri İbnü'l-Hatîb'den alan Memlûk tarihçisi İbn Hacer el-Askalânî de İbn Battûta'nın bilime katkısının oldukça sınırlı olduğunu bildirmektedir. İbn Hacer el-Askalânî, ed-Dürerü'l-Kâmine fî-Âyâni'lMi'eti 's-Sâmine, III, (Haydarabad: 1348-1380), 480-481. Bu tartışmalı konu bizim çalışmamızın dışındadır.

${ }^{17}$ İbn Battûta'nın Güneydoğu Asya hakkında verdiği bilgilerin değerlendirmesi için Bk. İsmail Hakkı Göksoy, "İbn Battûta'ya Göre Güney Doğu Asya Ülkeleri", Dini Araştırmalar Dergisi 4/12, (Ocak-Nisan 2002), 49-70.

${ }^{18}$ İbn Battûta, İbn Battûta Seyahatnamesi, 2004, 23. 
dünyada gezilmesi gereken ülkeler sadece Müslümanların hâkimiyetinde olan yerlerdir. Bu açıdan XIII. Yüzyılın ilk yarısında Anadolu'da yaşanan İslam hakkında yaptığı gözlemler ve bu gözlemlerini yukarıda bahsettiğimiz ülkelerle karşılaştırması eserini zengin bir hazine haline getirmektedir. Batıda oldukça fazla ilgi gören Marko Polo'dan çok daha geniş bir alanı gezmiş olması ve üç kıtada önemli kültür merkezleri hakkında zengin bilgiler vermesiyle İbn Battûta, Polo'nun eserini zenginlik açısından çok geride bırakmıştır. ${ }^{19}$ Bugüne kadar on iki dile çevrilen İbn Battûta'nın Seyahatnamesi'nin ne kadar önemli bir metin olduğu ortadadır. İbn Battûta'nın eseri üzerine yaptığı önemli çalışmasıyla bilinen David Waines'in ifadeleriyle söyleyecek olursak "okurları bugün hâlâ büyülemektedir., 20

\section{2. İbn Battûta'nın Anadolu Hakkındaki Gözlemleri}

İbn Battûta tarihçiler için önemli bir kaynak olmasının yanında sosyal hayat, âdetler, inançlar ve töreler hakkında verdiği bilgilerle antropologlar açısından da değerli bir eserdir. İbn Battûta, seyahatnamesinde yemek tarifleri, bayram ve matem giysileri, siyaset, tasavvuf gibi o dönemin insanıyla ilgili hemen her konuda bilgi vermiştir. Bilim tarihçisi A. L. Sarton ve oryantalist H. A. R. Gibb, İbn Battûta'nın eserinin ansiklopedik yönüne dikkat çekmişlerdir. Abdullah Abdülganî Gānim ise İbn Battûta'yı ilk antropologlardan biri olarak görmektedir. ${ }^{21} \mathrm{Bu}$ açıdan eser her disiplinin kendine ait metodolojileri açısından okunduğunda, pek çok sonuç elde etmek mümkündür. Çünkü olayları, gelenekleri, dönemin ruhunu aktarırken anlatısının merkezinde her zaman insan vardır. Siyasi olaylardan ziyade insanların yaşayışları, adetleri İbn Battûta'nın odak noktasıdır. Kroniklerde ya da tarih eserlerinde bulamayacağımız birçok hususu Rıhle'den öğrenmemiz mümkündür. ${ }^{22}$

Öncelikle İbn Battûta, Fas'ın Tanca şehrinde doğduğu ve yetiştiği için Anadolu hakkında verdiği bilgiler hem bir durum tespiti olarak hem de diğer İslam ülkeleriyle farklılıkları göstermesi açısından önemlidir. İbn Battûta'nın gördüğü Anadolu; Selçuklular ve Bizans’tan Osmanlı Devleti'ne geçişe denk gelen siyasi kırılma ve dönüşüm yüzyılının sonuna geliyor olmasına rağmen, şehir kültürü yeni gelen göçlerle birlikte zenginleşerek devam etmekteydi. ${ }^{23}$ Türk göçü ile birlikte Bizans kentleri, camiler ve medreseler gibi İslam eserleri ile yeniden inşa edilmiştir. Anadolu hakkındaki gözlemlerinde ilginç gelen konuların başında dinin algılanma şekli gelir. Günümüzde olduğu gibi, tek bir İslam'ın pratiğinden söz etmenin mümkün olmadığı bir dönemde İbn Battûta'nın tuttuğu kayıtlar, farklılıkları ve benzerlikleri göstermesi açısından ilginçtir. Bu bakış açısı ile İslam'ın Anadolu'da uygulanmasıyla ilgili olarak, seyyahın ilk dikkatini çeken, gündelik hayatta kadının durumuna dair tespitleridir. İbn Battûta'yı ilk şaşırtan husus kadınların kıyafetleridir. Hayret içerisinde kadınların yüzlerini örtmediğinden ve erkekler tarafindan görülmekten çekinmediklerinden bahseder. ${ }^{24}$ İbn Battûta'nın bu ifadeleri Anadolu'daki Müslümanlar arasında, kadının sosyal konumunu göstermesi açısından dikkat çekici bir örnektir. Gündelik hayatın içerisinde kadının oldukça aktif bir rol oynadığını göstermektedir. İbn Battûta'nın uğradığı şehirlerde (Burdur gibi) adına Allaha kurbanlar kesilmesi ise sosyal hayatta dini pratiklerin uygulandığının göstergesidir. İslam'ın günlük hayata yansımasıyla ilgili olarak eski Türk töreleri ile İslam dininin emirleri arasındaki uyuma dair örnekleri de görmek mümkündür.

\footnotetext{
${ }^{19}$ İbn Battûta, İbn Battûta Seyahatnamesi, 12.

${ }^{20}$ David Waines, İbn Battûta'nın Destansı Seyahati Bir Ortaçağ Maceraperestinin Hikâyeleri, çev. Ebru Kılıç, (İstanbul: Alfa Yyn., 2012), 9.

${ }^{21}$ Aykut, "İbn Battûta", 19/363.

${ }^{22}$ IX. yüzyıldan itibaren Ortaçağ İslam dünyasında gelişen seyahatname kültürü hakkında Bk. Houari Touati, Ortaçağda İslam ve Seyahat Bir Âlim Uğraşısının Tarihi ve Antropolojisi, çev. Ali Berktay (İstanbul: Yapı Kredi yayınları, 2016).

${ }^{23}$ Ross E. Dunn, Ibn Battuta'nın Dünyasi, 159.

${ }^{24}$ İbn Battûta, İbn Battûta Seyahatnamesi, 273.
} 
Yukarıda da ifade ettiğimiz gibi Alanya'da Selçuklu ülkesine ayak bastıktan sonra Antalya'dan Denizli’ye doğru giderken geçtiği Karaağaç hakkında verdiği bilgiler kendi dini taassubunu göstermesi açısından dikkat çekicidir. Kötülükleri ve eşkıyalık faaliyetlerini doğrudan Emevilere bağlaması bu taassubunu gösteren ilginç bir tutumdur. ${ }^{25}$ Hatta bu taassubunu Germiyan Türkmenlerini ${ }^{26}$ Yezid b. Muaviye'ye bağlamasıyla da göstermektedir. ${ }^{27}$ Oldukça zorlama olan bu rivayeti kendisinin aldığı ehlisünnet eğitimi ve İslam tarihine bakışı ile ilgili olduğu açıktır. İbn Battûta, Abbasi tarih yazıcılığı bakış açısıyla Emevi halifesi Yezid b. Muaviye'yi eşkıyalıkla özdeşleştirmektedir.

İbn Battûta, Anadolu kentlerini gezerken tekkelerde konaklamıştır. Bu bize XIV. yüzyılda Anadolu'da oldukça yaygınlaşan dini bir kurum olan tekkelerin sadece ibadet edilen mekânlar olmadığını, aynı zamanda kentlerden gelip geçen misafirlerin konakladığı mekânlar olduğunu göstermektedir. ${ }^{28}$ Dini hayatı tanzim eden bu kurumların sosyal hayatla da iç içe olduğu açıtır. Özellikle İbn Battûta'nın uzun süre kaldığı kentlerin dini mekânlar ile daha fazla donatıldığını düşünebiliriz. Şehirler hakkında bilgi verirken en çok bahsettiği kişiler arasında beylerden sonra fakihler ve hafizlar gelmektedir. Bu kayıtlar bize kent hayatında dini kurumların ve din adamlarının önemli bir yeri olduğunu göstermektedir.

Lâdik=Laodiakeia=Denizli hakkında verdiği Anadolu'nun dini demografisi ile alakalı bilgiler oldukça dikkat çekicidir. Kent nüfusunun büyük oranda Hıristiyanlardan oluştuğunu kaydeder. ${ }^{29} \mathrm{Bu}$ bilgi bize Müslüman-Hıristiyan din sınırının Denizli hattında oluştuğunu göstermektedir. Fakat bu kayıt XIII. yüzyılda yazan İbn Said Mağribi'nin Kitabu'l-Coğrafya'da Anadolu'nun bazı kentlerinin nüfusu ile ilgili verdiği bilgilerle çelişmektedir. ${ }^{30}$ İbn Said'in verdiği rakamların abartıllı olduğunu düşünebiliriz. Denizli ve civarının büyük oranda Türk nüfusundan oluştuğunu iddia etmektedir. Fakat 1332'li yıllarda İbn Battûta'nın bizzat gözlemlerine dayalı verdiği bilgilerde Denizli'nin Hıristiyan nüfusu daha fazladır. ${ }^{31}$

Aldığı dini eğitimin etkisini eserinde bariz şekilde gördüğümüz İbn Battûta, Anadolu'daki dini çeşitliliğe farklı bir bakış açısı ortaya koymuştur. Bu durumu en açık gösteren örnek Birgi'de Yahudi doktorla karşılaşması gösterilebilir. Aydınoğlu Mehmed Bey'in meclisinde otururken Yahudi doktorun huzura gelmesiyle, kadı ve müderris gibi din adamlarının dahi ayağa kalkmasına İbn Battûta oldukça sert bir tepki göstermiştir. Kadının, müderrisin ve hatta sultanın bu saygısı karşısında oldukça şaşıran İbn Battûta neden bu şekilde davrandıklarını anlamaya çalışmıştır. Mehmed Bey ve huzurundakilerin hekime saygı göstermeleri toplumsal ihtiyaçlarla ilgili gözükmektedir. İbn Battûta'nın neden ayağa

\footnotetext{
${ }^{25}$ Emevîlerin Mevali politikası, Hz. Ali ailesine yönelik baskı ve şiddet siyaseti, Kerbelâ olayı, Haccac-1 Yusuf'un (Zalim Haccac'ın) zulme varan uygulamalarına sessiz kalmaları, isyanları bastırmak adına Mekke ve Medine'ye zarar vermekten çekinmemeleri bu bakış açısında etkili temel hususlardır. Emevîler; İslam fetihlerinin zirveye ulaştığı bir hanedanlık olarak kabul edilir. Fakat bu fetih politikasının dahi cizye ve haraç elde etmeye yönelik olduğuna dair görüşler bulunmaktadır. Bir sünnî İslâm alimi olan İbn Battûta da bu düşüncelerin etkisinde kalmış olmalıdır. Emevi dönemi hakkında Bk. İsmail Yiğit, Emevîler (661-750) (İstanbul: İsam Yayınları, 2016); Adnan Demircan, Emevîler (İstanbul: Beyan Yayınları, 2015); Muhammed Süheyl Takkûş, Emevî Devleti Tarihi, çev. Mücahit Yüksel (İstanbul: Hikmetevi yayınevi, 2016).

${ }^{26}$ Germiyanoğulları Beyliği’nin kökenleri hakkında tartışmalar devam etmektedir. Bk. Dmitry Korobeynikov, "Royal Titles the Germiyanoğulları", Germiyanoğulları Beyliği Bildiriler, haz. Mehmet Ersan-Mehmet Şeker, (Ankara: 2017).

${ }^{27}$ İbn Battûta, İbn Battûta Seyahatnamesi, 279.

${ }^{28}$ Selçuklu dönemi Anadolu'da yaşanan kültür ve din hayatı hakkında bk. Claude Cahen, Osmanlılardan Önce Anadolu, çeviri: Erol Üyepazarcı (İstanbul: Tarih Vakfi Yurt Yayınları, 2000), 207-222.

${ }^{29}$ İbn Battûta, İbn Battûta Seyahatnamesi, 279.

${ }^{30}$ Yaşar Yücel, Anadolu Beylikleri Hakkında Araştırmalar, I, 2. Baskı (Ankara: Türk Tarih Kurumu Yayınları, 1991), 183-203.

${ }^{31}$ Claude Cahen, “İbn Said Sur L’asie Mineure”, Tarih Arașttrmaları Dergisi (1969), 43.
} 


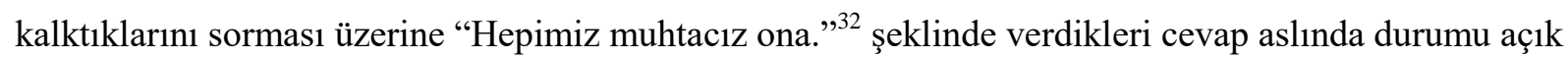
bir şekilde izah etmektedir. Hastalandıklarında insanların şifa aradığı doktora saygı göstermek dini taassubun önüne geçmiştir. İbn Battûta'nın kayıtlarında Birgi'nin çok önemli ve detaylı bir yer kapladığını görüyoruz. Bu durum kentin, Batı Anadolu'nun en önemli merkezlerinden biri olduğunu göstermektedir.

Birgi'den sonra Tire'ye ve Ayasuluk'a uğradıktan sonra İzmir'i geçen İbn Battûta, daha sonra Manisa'da Türk gelenekleriyle ilgili dikkat çekici bir cenaze ve sonrasındaki ritüellerle ilgili kayıt tutmuştur. Manisa'da hüküm süren Sârûhân Bey'i ziyaret ettiği sırada birkaç ay önce ölmüş oğlunun türbesini gören İbn Battûta, Bey'in oğlunu nasıl defnettiğini ve türbenin inşa sürecini oldukça detaylı bir şekilde aktarmaktadır. Özellikle Sârûhân Bey'in bayram gecesini ve sabahını türbede geçirmesi; cesedin kalaylı demir bir tabutta saklanması; bedenin çürümeye başlamasıyla kötü kokular yaymasıyla birlikte bu kokunun kaybolması için çatısı açık bir türbeye asılması; daha sonra yere indirilerek elbiselerinin tabut üzerine konulmass ${ }^{33}$ İslam dininin ölü gömme ritüellerine uygun gözükmemektedir. Dolayısıyla bu adetlerin Orta Asya Türk gelenekleriyle doğrudan ilişkili olduğunu söyleyebiliriz. ${ }^{34}$ İbn Battûta'nın Manisa ve Balıkesir ile ilgili kayıtlarını dikkate alarak daha önce bahsettiği kentlerle karşılaştırdığımızda, İslami pratiklerde farklılıkların olduğunu söyleyebiliriz. Balıkesir sultanı Demirhan hakkında sarf ettiği "meymenetsiz" ve "hayırsız" gibi sıfatlar ve dini görüşüyle ilgili söylediklerinden, Demirhan'ın kendisine çok fazla izzeti ikramda bulunmadığını düşünebiliriz. ${ }^{35}$ İbn Battûta, Anadolu halkının Hanefi mezhebinden olduğunu söyleyerek bunun çok faziletli bir mezhep olduğunu belirtmesi de dikkat çekicidir. Bu kayıttan anladığımıza göre, İbn Battûta'nın yaşadığı dönemde mezhebi tartışmaların seyyahın gündeminde olduğunu göstermektedir. İbn Battûta, Kaderî, Râfıdî (Rafizi), Mutezile, Harici gibi mezhepleri sapkın olarak görmektedir. ${ }^{36}$ Seyyahımız, genel anlamda Türklerin ehlisünnet olduğunu söyleyerek överken çok ilginç bir kayıt vererek halkın esrar çiğnemekten çekinmediklerini ifade etmektedir. Bu kayıt Anadolu'da yaşanan İslam ile alakalı oldukça ilgi çekici bilgiler vermektedir. Esrar kullanılması ve dışarıdan kente gelen bir İslam aliminin bunu gözlemleyerek kaydetmesi, esrarın kullanılmasının oldukça yaygın olduğunu göstermektedir. ${ }^{37}$

İbn Battûta'nın 1330'lu yıllarda Anadolu'da yaşanan İslam konusunda verdiği bilgiler içerisinde en dikkat çeken kayıtlardan bir diğeri de kentlerde yaşanan İslam ile kırsalda yaşanan arasında gördüğü farklılıklardır. İbn Battûta daha çok standart bir mutasavvıf gözüyle kentlerde yaşanan İslam'ı idealize ederken kırsal alanda yaşanan dini hayattan pek bahsetmez. Seyyahın bu bakış açısı; tasavvufi elit kimliği ile daha çok beyler etrafında ve şehirlerde ağırlanmasından dolayı kırsal hayata dair ayrıntılı bir şahitliğinin bulunmamasıyla izah edilebilir. Dolayısıyla İbn Battûta'nın gözlemleri, kentlerde yaşanan ideal ehlisünnet İslam inancı (ve daha çok Hanefi mezhebi) üzerinden bakan birinin değerlendirmeleridir. İbn Battûta, sûfîlere ve zâhidlere duyduğu yakınlık sebebiyle onların sözlerini ezberlemiştir. Eseri bu yönüyle dönemin tasavvuf hayatı hakkında çok kıymetli bilgiler vermektedir. ${ }^{38}$ Bu sebeple, Anadolu İslam'1 olarak nitelenen XIV. yüzyıl Aleviliğinin nasıl bir

\footnotetext{
${ }^{32}$ İbn Battûta, İbn Battûta Seyahatnamesi, 291.

33 İbn Battûta, Ibn Battûta Seyahatnamesi, 294.

${ }^{34}$ Emel Esin, İslamiyetten Önceki Türk Kültür Tarihi ve İslama Girişs (Türk Kültürü El-Kitabı, II, Cild I/b'den Ayrı Basım), (İstanbul: Edebiyat Fakültesi Matbaası 1978), 104-105.

${ }^{35}$ İbn Battûta, Ibn Battûta Seyahatnamesi, 295.

${ }^{36}$ İbn Battûta'nın mezhepler ve Sufi tarikatları değerlendirmesi hakkında Bk. David Waines, İbn Battûta'nın Destansı Seyahati, 157-172. Mahmut Askeri Küçükkaya, İbn Battûta Seyahatnamesinde Tasavvufí Kültür (İstanbul: Nizamiye Akademi, 2021). Selçuklu ve Beylikler devrinde Anadolu'daki dini hayat hakkında Bk. Ahmet Yaşar Ocak, "Selçuklular ve Beylikler Devrinde Tasavvufî Düşünce”, Anadolu Selçukluları ve Beylikler Dönemi Uygarlığı, haz. Ahmet Yaşar Ocak (Ankara: Kültür ve Turizm Bakanlığı, 2006), 1/429-439.

${ }^{37}$ İbn Battûta, İbn Battûta Seyahatnamesi, 274.

${ }^{38}$ Aykut, "İbn Battûta”, 19/363.
} 
itikat ve ibadet üzerinde olduğunu tespit edecek veriler sunmamaktadır. ${ }^{39}$ Dolayısıyla bu çalışmamızda daha çok kentlerde İslam'ın nasıl yaşandığına dair seyyahın gözlemlerini değerlendirirken köydeki durumlara dair tespit yapma imkânına sahip değiliz. Fakat bu durumun tek istisnasını Sinop'ta kaldığı zaman bahsettiği tavşan hikâyesinde gözlemliyoruz. İbn Battûta'nın Maliki mezhebine mensup olması sebebiyle ellerini iki yana salarak namaz kılması üzerine Şii olduğuna dair bir şüphe uyanmış ve tavşan etiyle teste tâbi tutulmuştur. ${ }^{40} \mathrm{Bu}$ çok enteresan ayrıntı Anadolu kentlerinde Hanefi fikhının hâkim olduğunu ve hatta ehlisünnet mezheplerinden olan Malikiliğin dahi çok da iyi bilinmediğini göstermektedir. İbn Battûta, Anadolu Aleviliğini Rafızi olarak nitelemiştir. Burada Şiilikle Anadolu Aleviliğini aynı kategori içerisinde gösterdiğine şahit oluyoruz. Anadolu kentlerinde diğer İslam beldelerinde olduğu gibi Müslümanlar ile gayr-1 Müslimler farklı mahallelerde yaşamaktaydılar. İbn Battûta uğradığı hemen hemen her şehirde bu tespiti yapmaktadır. Anadolu'da Rumlar, Yahudiler farklı mahallelerde ve birbirlerinden ayıran büyük duvarlarla çevrili mahallelerde yaşamaktadırlar. Şehri tanımlarken Cuma Camii, medrese, hamam ve çarşı gibi mekânları anlatmıştır. İbn Battûta'nın eseri sayesinde İslam dünyasında XIV. yüzyılda ortalama bir kent modelinin olduğunu ve bunun hemen hemen bütün İslam beldelerinde benzer şekillerde mimari eserlerle temsil edildiğini söyleyebiliriz. ${ }^{41}$ İbn Battûta'nın eseri sayesinde XIV. yüzyılın ilk yarısında İslam kentlerinde insanların sosyalleşme faaliyetlerini de tespit edebiliyoruz. Dinin oldukça kuşatıcı bir hayat felsefesi sunduğu İslam kentinde insanların sosyal hayatları da dinî emirler çerçevesinde istenen ibadetlerle gerçekleşmekteydi. En dikkat çeken ve halkın hemen hemen tamamını etkileyen sosyal faaliyetlerin başında güzel sesli gençlerin Kuran'dan belli sureleri okuması gelmektedir. ${ }^{42}$

Seyahatine Burdur, Isparta yönünde devam eden İbn Battûta, Eğirdir'i anlatırken şehrin zenginliklerinden bahsettiği gibi dini hayatına dair önemli ipuçları da vermektedir. Örneğin Isparta’yı anlatırken herhangi bir medreseden bahsetmezken Eğirdir'deki medreseyi detaylı bir şekilde tasvir etmektedir. Bu medresede hocalık yapan kişilerin Mısır ve Suriye gibi İslam dünyasının önemli merkezlerinde eğitim aldıklarını vurgulamaktadır. Bu değerli bilgi, Anadolu ile İslam'ın önemli merkezleri arasında bilgi ve insan akışının olduğunu göstermektedir. Dolayısıyla bu durum siyasi sınırlarla dini sınırların aynı olmadığının ve Anadolu ile Suriye-Mısır arasındaki kültürel etkileşimin kanıtıdır. Fakat İbn Battûta'nın Eğirdir'de bahsettiği Muslihiddîn adlı hocanın kimliği hakkında daha fazla bilgi sahibi değiliz. Anadolu'da yaşayan önemli kişilere ait biyografi kitaplarından mahrum olduğumuzdan Muslihiddin hakkındaki bilgilerimiz İbn Battûta'nın kayıtlarıyla sınırlıdır. Muslihiddin, muhtemelen Anadolu'da doğmuş, Mısır ve Suriye gibi yüksek İslam kültürünün yaşandığı merkezlerde eğitim almış bir kişiydi. Ayrıca İbn Battûta, Eğirdir sultanının babasının Mısır'da kaldığını ve hac görevini yerine getirdiğini anlatıyor. Bu da dönem şartları içerisinde sosyal hareketliliğin büyük oranda dini motivasyonlarla gerçekleştiğinin kanıtıdır. ${ }^{43}$ İbn Battûta, şehirlerde sosyal hayatın en canlı hususlarından biri olan yeme-içme alışkanlıklarını ${ }^{44}$ da ibadetlerle

\footnotetext{
${ }^{39}$ Anadolu'daki tasavvuf hayatı ve tarikatlar hakkında Bk. Resul Ay, "Tasavvufî Hayat ve Tarikatlar", Anadolu Selçukluları ve Beylikler Dönemi Uygarlı̆̆ı, ed. Ahmet Yaşar Ocak (Ankara: Kültür ve Turizm Bakanlığı, 2006), 1/459-465.

40 İbn Battûta, İbn Battûta Seyahatnamesi, 308.

${ }^{41}$ İbn Battûta, İbn Battûta Seyahatnamesi, 274.

42 İbn Battûta, İbn Battûta Seyahatnamesi, 275.

${ }^{43}$ İbn Battûta, İbn Battûta Seyahatnamesi, 277.

44 İbn Battûta'nın Seyahatnâmesi'nde yemek kültürü ile ilgili oldukça zengin bilgiler bulunmaktadır. Mehmet Ali Kapar, "İki Seyyah Bir Kültür: Broquière ve İbn Battûta Seyahatnâmelerine Göre Türklerde Yemek Kültürü”, SEFAD, 41 (2019), 427-444.
} 
ilişkilendirmektedir. Hatta kendisine ikram edilen tiriti Hz. Peygamberin sünneti ile ilişkilendirmiştir. ${ }^{45}$

İbn Battûta, seyahatnamesi'nde sadece Müslümanların değil Hıristiyanların gündelik yaşamlarına dair, biraz da magazinsel bilgiler vermektedir. Özellikle Denizli ile ilgili kayıtlarda bahsettiği, hamamlarda güzel Rum kadınların erkeklerle birlikte eğlenmelerini günahkâr bir tutum olarak belirtmesi enteresandır. Fakat fikıh eğitimi almış Müslüman bir fakihin tam olarak emin olmadığı bir rivayeti zikretmesi dikkat çekici olmakla beraber eserinde bahsettiği bazı hadiseleri ilim meclislerinde ya da günlük hayat içerisinde görüştüğü kişilerden almış olması kuvvetle muhtemeldir. Ayrıca aynı ülkede yaşayan Hıristiyanlarla komşuluk yapan Müslümanlar da bu rivayetleri derlemiş olabilir. Bu tür sözlü rivayetlerden de elde etiği bilgilerden anlaşıldığına göre kadının da hamamla olan ilişkisini kaydetmektedir. ${ }^{46}$ İbn Battûta'nın Denizli'de olduğu gibi birçok şehirde fakihler sayesinde kentin ileri gelenleriyle iletişim kurduğunu anlıyoruz. İbn Battûta burada Ramazan ayını karşılamıştır. Bu açıdan Denizli'de Ramazan ayında yapılan her bir dini görev İbn Battûta tarafından titizlikle kayda geçirilmiştir. Ramazan Bayramı'nda fakirler için kurban kesilmesinin de dini bir görevden ziyade bir gelenek olduğu anlaşılmaktadır. Özellikle herkese yemek ikram edilmesi yaygın bir âdet gibi gözükmektedir.

Denizli'den sonra Tavas'a geçen İbn Battûta burası ile ilgili ilginç bir bilgi veriyor. Daha önce uğradığı hiçbir şehirde sahabe mezarından bahsetmezken Tavas'ta kalenin adının bir sahabe ile ilişkilendirmesi dikkat çekicidir. ${ }^{47}$ İbn Battûta'nın Tavas'ta bahsettiği sahabe Suhayb ile ilgili bilgiye başka kaynaklarda rastlanmamaktadır. Tavas halkı bir efsane gibi şehirlerinde bir sahabenin medfun olduğuna inanmaktaydılar. Bu sözlü rivayeti İbn Battûta duymuş ve notlarına kaydetmiş olmalıdır. İbn Battûta'nın bu rivayeti nakletmesinin iki açıklaması olabilir: Öncelikle şehirlere kutsiyet kazandırmak için her kültürde ya da inançta bu tür rivayetlere ihtiyaç duyulmaktadır. Tavas halkı da bu tür bir rivayeti nesilden nesile aktararak şehirlerine dini bir anlam yüklemişlerdir. İkinci olarak ise İbn Battûta bu rivayeti, eserine alarak daha canlı bir hale getirmek istemiş olabilir. İbn Battûta'nın Tavas'ta bahsettiği sahabe mezarı rivayetinin başka açıklamaları da olabilir. XIII. ve XIV. yüzyıllarda Batı Anadolu'ya yoğun bir Türk göçünün olduğu bilinmektedir. Bu göç başlı başına bir nüfus hareketinden çok daha fazla anlamlar içermektedir. Dolayısıyla bu sahabe mezarı mekânın her anlamda dönüştürüldüğünün bir göstergesidir. Bu rivayet dini bir dönüşüm yaşandığının en güzel kanıtlarından biridir. Hıristiyanların yoğun olarak yaşadığı bu bölgenin kısa bir sürede Müslüman kimliğine bürünmesi, tarihsel kişiliklere atıf yaparak çok daha kuvvetli bir temele oturtulmaya çalışılması, daha doğrusu buna ihtiyaç duyulması oldukça kuvvetli bir ihtimal olarak karşımıza çıkmaktadır. Ayrıca İbn Battûta'nın doğruluğunu tam olarak kendisinin de ispatlayamayacağı bu türden rivayetleri (sahabe rivayeti gibi) eserine bilinçli olarak aldığını düşünebiliriz. Bu duruma bir diğer örnek ise Milas'ta Baba Şüş̧eri'nin 150 yaşından fazla olduğunu aktarmasıdır. Dolayısıyla sahabe rivayetini de bu bağlamda değerlendirebiliriz. Sinop ziyareti sırasında da Bilal-i Habeşi'nin kabrinin burada olduğundan bahsetmesi durumu da Tavas'taki sahabe mezarı hikâyesi ile aynı kaygılardan doğmuştur.

İbn Battûta, uzun seyahatleri süresince tekkelerde, zaviyelerde ve Ahi konaklarında kalmıştır. Dolayısıyla tekkelerin sadece dini fonksiyonlarının olmadığını bunun yanında gelen geçen yolcuların konakladığı yerler olduğunu söyleyebiliriz. ${ }^{48}$ İbn Battûta, katıldığı meclislerde fikıh âlimlerine

\footnotetext{
${ }^{45}$ İbn Battûta, İbn Battûta Seyahatnamesi, 278.

${ }^{46}$ İbn Battûta, İbn Battûta Seyahatnamesi, 279.

${ }^{47}$ İbn Battûta, İbn Battûta Seyahatnamesi, 281.

${ }^{48}$ İbn Battûta'nın eserinde Ortaçağ Anadolusu'nun önemli iktisadi ve içtimaî ve bir o kadar da dini bir teşkilatı olan Ahilik ile ilgili kayıtların değerlendirmesi hakkında bk. Mehmet Şeker, İbn Batuta'ya Göre Anadolu'nun
} 
hükümdardan daha çok değer verildiğini ve bunun Türklere ait bir özellik olduğunu özellikle vurgulamaktadır. ${ }^{49}$ Ayrıca geleneksel Kuran okuma alışkanlığı dışında hadislerin de bu meclislerde okunduğunu görüyoruz. Hatta Aydınoğullarının merkezi Birgi'de Mehmed Bey İslam dininin daha iyi anlaşılması için hadislerin öneminin farkına varmış ve bunların Türkçeye çevrilmesini istemiştir. ${ }^{50}$ Aydınoğulları döneminde daha çok dini kitaplar olmak üzere birçok eserin Türkçeye çevrildiğini biliyoruz. ${ }^{51}$ XIV. yüzyıl beylikler dünyasında birçok dini eserin Türkçeye tercüme edilmesi İslam dininin daha iyi anlaşılması amacıyla Beylerin inisiyatifi ile desteklenmiştir. Dolayısıyla İbn Battûta'nın kayıtları bu durumu teyit etmektedir.

\section{SONUÇ}

İbn Battûta'nın Seyahatnamesi, sadece bir gezi günlüğü değildir. Gezdiği kentlerin dini, sosyal ve kültürel özellikleri hakkında detaylı bilgiler vermektedir. Bu çalışmada daha çok Anadolu'nun XIV. yüzyılının bazı kentlerinde İslam inancının nasıl yaşandığına dair birtakım tespitlerde bulunmaya çalışılmıştır. Araştırmamız her ne kadar İbn Battûta'nın gezdiği kentlerle sınırlı olsa da verdiği bilgiler ile genel bir tasvir oluşturulabilir. İbn Battûta'nın Anadolu kentlerine dair gözlemlerinde halk ile medreseler arasındaki ilişkileri gösteren çok enteresan bilgiler vardır. İbn Battûta, Birgi'de evinde misafir olarak kaldığı kişiye daha önce tanıştığı Muhyiddin adlı müderrisin yerini sorduğunda; ev sahibinin bu müderrisin talebesi olduğu cevabını almıştır. ${ }^{52}$ İbn Battûta'yı son derece şaşırttığını anladığımız bu durum, halk ile medreseler arasında oldukça canlı bir iletişimin olduğunu göstermektedir. Dolayısıyla halkın dini konularda medreselerden beslendiğini göz önünde bulunduracak olursak, İslam'ın XIV. yüzyıl Anadolu'sunda sosyal hayata temas ettiğini ifade edebiliriz. Bu bağlamda Ortaçağ Anadolu kültür tarihi araştırmalarında ortaya çıkan eksikliklerin bir nebze de olsa giderilmesinde İbn Battûta'nın kayıtlarının oldukça faydalı olduğunu görmekteyiz. Seyahatname her ne kadar Selçukluların tarih sahnesinden silinmesinden yaklaşı otuz yıl sonra kaleme alınmış olsa da Selçuklu Devleti ve Beylikler devri dini hayatından bahsetmesi açısından oldukça önemli bir kaynaktır. 1330 gibi Selçukluların sonu, erken Osmanlı devri gibi tam bir geçiş döneminin, kültür hayatına dair verdiği kayıtların çok titiz bir şekilde incelenmesi birçok sorunu aydınlatmaya yarayacaktır. Ayrıca siyasi tarih kaynakları dışında İbn Battûta'nın Seyahatnamesi gibi bir eser, kroniklerin söylemediği, aydınlatmadığı birçok konuyu da açıklamaktadır.

İbn Battûta'nın seyahatleri sırasında İspanya'daki İslam varlığı ciddi manada tehdit altındaydı. Bu sebeple Anadolu'da İslam'ın yayılması ve Bizans medeniyetinin çöküşünü gören Müslüman fakihin gözlemlerinin her satırını dikkatle okumak gerekmektedir. İbn Battûta, Faslı hükümdarının İspanya'yı tekrar fethetmek için son ama tamamen beyhude bir teşebbüse girişmesinden önce Anadolu'daki Türk beyliklerini dolaşmıştır. İber yarımadasında İslam'ın yavaş yavaş silinmesi karşıllı̆ında Anadolu'da yükselmeye başlaması, İbn Battûta gibi bir âlimi teselli etmiş olabilir.

Sosyal-Kültürel ve İktisadî Hayatı İle Ahîlik (Ankara: Kültür Bakanlığı HAGEM, 1993). Ayrıca Denizli tarihi hakkında Bk. Tuncer Baykara, Denizli Tarihi Íkinci Kısım 1070-1429 (İstanbul: Fakülteler Matbaas1, 1969). Ahilik hakkında Bk. Yusuf Ekinci, Ahîlik ve Meslek Eğitimi (İstanbul: Milli Eğitim Bakanlığı Yayınları, 1990).

${ }^{49}$ İbn Battûta, İbn Battûta Seyahatnamesi, 289.

${ }^{50}$ İbn Battûta, İbn Battûta Seyahatnamesi, 290.

${ }^{51}$ Murat Keçiş, "Batı Anadolu Beyliklerinde Türkçe”, IV. Uluslararası Dünya Dili Türkçe Sempozyumu (Muğla: Muğla Sitkı Koçman Üniversitesi, Aralık 2011).

${ }^{52}$ İbn Battûta, İbn Battûta Seyahatnamesi, 288. 


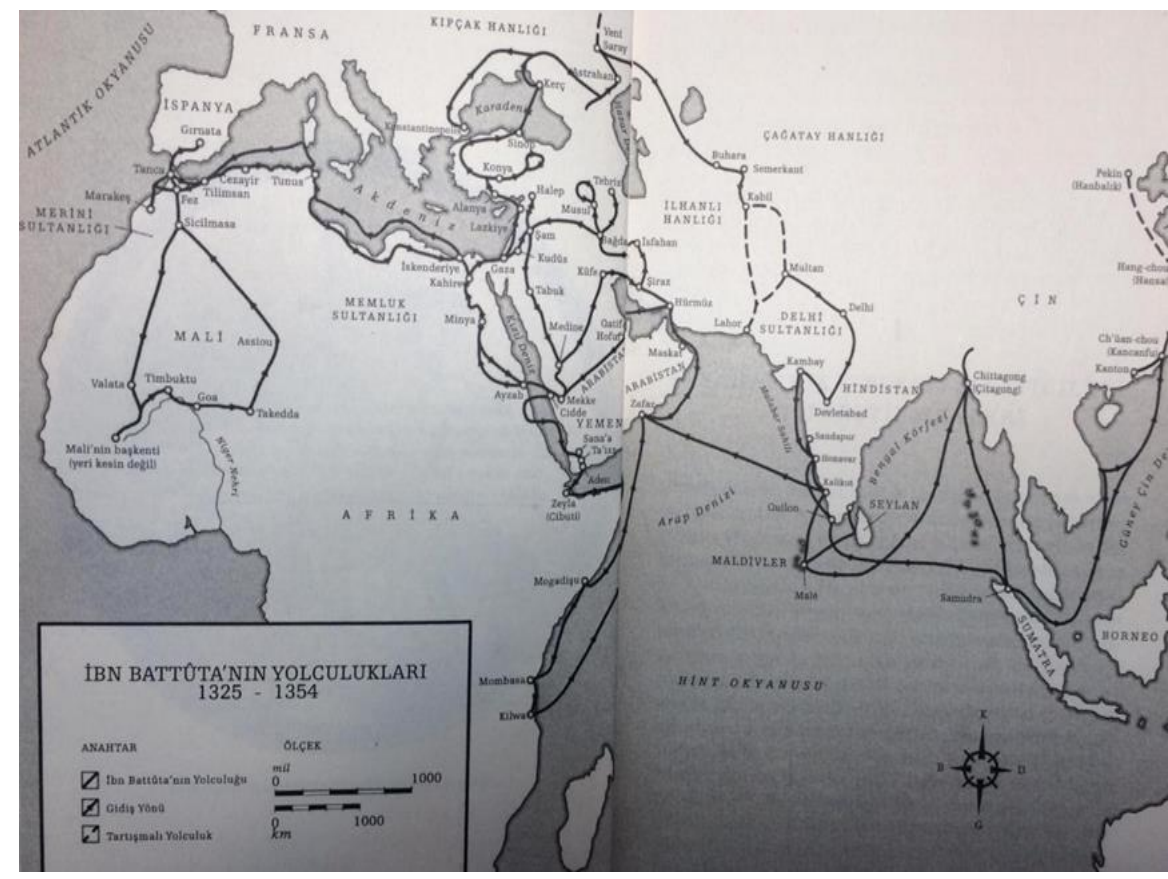

Şekil 1. David Waines 'in İbn Battûta 'nın Destansı Seyahati kitabından eklenmiştir (s. 14-15)

Author Contributions / Yazarların Katkısı: This article is a work with two-authors. The contribution of the aforementioned authors to the preparation of the article is equal. / Bu makale, iki yazarlı bir eserdir. Makalenin hazırlanmasına söz konusu yazarların katkısı eşittir.

Funding / Finansman: This research received no external funding. / Bu araştırma herhangi bir dış fon almamıştır.

Conflicts of Interest / Çıkar Çatışması: The author declare no conflict of interest. / Yazar, herhangi bir çıkar çatışması olmadığını beyan eder.

\section{KAYNAKÇA}

Allouche, Adel. "A Study of Ibn Battūtah's Account of His 726/1326 Journey Through Syria and Arabia". Journal of Semitic Studies 35/2 (Autumn 1990), 283-299.

Altıntaş, Meryem. İbn Battûta'ya Göre Anadolu Şehirlerinde Siyâsî, Dinî, İlmî, İ̧̧timâ̂ ve İktisâdî Hayat. İstanbul: İstanbul Üniversitesi, Sosyal Bilimler Enstitüsü, Yayınlanmamış Yüksek Lisans Tezi, 2019.

Ay, Resul. "Tasavvufî Hayat ve Tarikatlar”. Anadolu Selçukluları ve Beylikler Dönemi Uygarlığı. Editör: Ahmet Yaşar Ocak. 1/459-465. Ankara: Kültür ve Turizm Bakanlığı, 2006.

Aykut, A. Sait. "İbn Battûta". Türkiye Diyanet Vakfi İslâm Ansiklopedisi, 19/361-368. İstanbul: TDV Yayınları, 1999.

Baykara, Tuncer. Denizli Tarihi İkinci Kısım 1070-1429. İstanbul: Fakülteler Matbaası, 1969.

Cahen, Claude. "İbn Said Sur L'asie Mineure". Tarih Arasttrmaları Dergisi 6 (1968), 41-50.

Cahen, Claude. Osmanlılardan Önce Anadolu. çev. Erol Üyepazarcı. İstanbul: Tarih Vakfı Yurt Yayınları, 2000.

Demircan, Adnan. Emevîler. İstanbul: Beyan Yayınları, 2015.

Dunn, Ross E. İbn Battuta'nın Dünyası. çev. Yeşim Sezdirmez, İstanbul: Klasik Yayınları, 2004.

Ebû Abdullah Muhammed İbn Battûta Tancî. İbn Battûta Seyahatnamesi. çev. A. Sait Aykut. İstanbul: Yapı Kredi Yayınları, 9. Basim, 2019.

Ekinci, Yusuf. Ahîlik ve Meslek Eğitimi. İstanbul: Milli Eğitim Bakanlığı Yayınları, 1990.

Esin, Emel. İslamiyetten Önceki Türk Kültür Tarihi ve İslama Giriş (Türk Kültürü El-Kitabı, 2, Cild 1/b'den Ayrı Basım). İstanbul: Edebiyat Fakültesi Matbaası, 1978.

Göksoy, İsmail Hakkı. “íbn Battûta'ya Göre Güney Doğu Asya Ülkeleri”. Dini Araşttrmalar Dergisi 4/12 (Ocak-Nisan 2002), 49-70.

İbn Battûta Tanci. İbn Battûta Seyahatnamesi, 2 Cilt. Çeviri, inceleme ve notlar: A. Sait Aykut. İstanbul: YKY, 2004.

İbn Cübeyr. Endülüsten Kutsal Topraklara. çev. İsmail Güler. İstanbul: Selenge Yayınları, 2003. 
İbn Hacer el-Askalânî. ed-Dürerü'l-Kâmine fî-Âyâni'l-Mi'eti's-Sâmine. Haydarabad: 1348-1380, 3.

İbn Haldun. Mukaddime. Hazırlayan: Süleyman Uludağ, 2 Cilt. İstanbul: Dergah Yayınları, 4. Baskı, 2005.

İbn Haldun. Mukaddime. çev. Zakir Kadirî Ugan, İstanbul: Millî Eğitim Bakanlığı Yayınları, 1990.

Kapar, Mehmet Ali. “İki Seyyah Bir Kültür: Broquière ve İbn Battûta Seyahatnâmelerine Göre Türklerde Yemek Kültürü”. SEFAD, 41 (2019), 427-444. https://doi.org/10.21497/sefad.586682

Karaman, Suat. İbn Battûta'ya Göre XIV. Yüzyıl Anadolu Kültür Hayatı. Karabük: Karabük Üniversitesi, Sosyal Bilimler Enstitüsü, Yüksek Lisans Tezi, 2015.

Kavak, Abdulcebbar. "Seyyah İbn Battûta'nın Gözüyle 14. Asır İran Toplumunda Tasavvuf”. Şırnak Üniversitesi İlahiyat Fakültesi Dergisi 11/25 (Aralık 2020), 432-456.

Keçiş, Murat. "Batı Anadolu Beyliklerinde Türkçe”. IV. Uluslararası Dünya Dili Türkçe Sempozyumu. 1/651-656. Muğla: Muğla Üniversitesi, Aralık 2011.

Köprülü, Mehmet Fuad. Anadolu'da İslamiyet. İstanbul: Alfa Yayınları, Mart 2017.

Koçyiğit, Tahsin. "İbn Battûta'nın Karadeniz seyahati üzerine bazı mülahazalar”. Din Bilimleri Akademik Araştırma Dergisi 9/4 (2009). 53-73.

Korobeynikov, Dmitry. "Royal Titles the Germiyanoğulları". Germiyanoğulları Beyliği Bildiriler. Yayına Hazırlayanlar: Mehmet Ersan-Mehmet Seker. 303-310. Ankara: 2017.

Küçükkaya, Mahmut Askeri. İbn Battûta Seyahatnamesinde Tasavvufî Kültür. İstanbul: Nizamiye Akademi, 2021.

Ocak, Ahmet Yaşar. "Selçuklular ve Beylikler Devrinde Tasavvufî Düşünce". Anadolu Selçukluları ve Beylikler Dönemi Uygarlığı. haz. Ahmet Yaşar Ocak. 1/429-439. Ankara: Kültür ve Turizm Bakanlığı, 2006.

Ocak, Ahmet Yaşar. Türkiye Sosyal Tarihinde İslamın Macerası, Makaleler İncelemeler. İstanbul: Timaş Yayınları, 2010.

Şehitoğlu, Betül Ok. Seyahatname Sosyolojisi: İbn Batuta'nın Gizemli Dünyasına Sosyolojik Bir Bakış. Konya: Çizgi Kitabevi, 2021.

Şeker, Mehmet. İbn Batuta'ya Göre Anadolu'nun Sosyal-Kültürel ve Íktisadî Hayatı İle Ahîlik. Ankara: Kültür Bakanlığı HAGEM, 1993

Takkûş, Muhammed Süheyl. Emevî Devleti Tarihi. çev. Mücahit Yüksel. İstanbul: Hikmetevi yayınevi, 2016.

Touati, Houari. Orataçağda İslam ve Seyahat Bir Âlim Ŭgraşısının Tarihi ve Antropolijisi. çev. Ali Berktay. İstanbul: Yapı Kredi yayınları, 2. Basım, 2016.

Üstündağ, Mehlika. "İbn Battuta Seyahatnamesine Göre XIV. Yüzyıl İran Coğrafyasında Sosyal Yaşam”. Irraniyat Dergisi / Journal of Iranian Studies 1/2 (2017), 45-65.

Vryonis, Speros. The Decline of Medieval Hellenism in Asia Minor and the Process of Islamization from the Eleventh through the Fifteenth Century. Berkeley- Los Angeles- Londra: University of California Press, 1971, yeniden basim 1986.

Waines, David. İbn Battûta'nın Destansı Seyahati Bir Ortaçağ Maceraperestinin Hikâyeleri. çev. Ebru Kılıç, İstanbul: Alfa Yayınları, 2012.

Yiğit, İsmail. Emevîler (661-750). İstanbul: İsam Yayınları, 2016.

Yücel, Yaşar. Anadolu Beylikleri Hakkında Araştırmalar, 2 Cilt. Ankara: Türk Tarih Kurumu Yayınları, 2. Basım, 1991. 